\title{
8 The Canonical Shape of the Psalter as Cotexts for Understanding Psalm 110: With Special Reference to Psalms 1-2 and Books I-IV
}

As shown in the last chapter, Psalm 110 should be read in a messianic andeschatological sense. The poet has employed rhetorical and literary devices and techniques to explicate the messianic figure that is both a royal and a priestly person. Does this messianic reading of Psalm 110 align with the understanding offered by the canonical shape of the Psalter? Or do the cotexts of Psalm 110 share the same theological concerns? The purpose of this chapter is to set out to prove that they do share the messianic reading of Psalm 110, as we have delineated in our last chapter.

The approach adopted here is to treat the Psalter, particularly certain psalms, as "cotexts" of Psalm 110. With 150 psalms in the Psalter, the process has to be selective. Nonetheless, based on certain semantic-thematic links, we will focus our study on Psalms 1-2, viewing them as the programmatic introduction to the Psalter. We will review the canonical shape of Books I-IV in view of Psalms 1-2, paying particular attention to Psalms 72 and 89 because of their strategic positions in Books II and III. Afterwards, we will examine Book IV in view of the message in Psalm 89. All of the above studies will be the focus of this chapter. (In our next chapter, the immediate "cotext" of Psalm 110, Book V, will be investigated, which should illuminate exegetical insights from Psalms 108-109 and 132. At the close of our next chapter, we will consider the theological implications of Psalm 110 in view of the other psalms and the nonpsalm texts of Genesis 14, Numbers 22-24, and 2 Samuel 7).

\subsection{A Programmatic Understanding of Psalm 110: Psalms 1-2 as an Editorial Introduction to the Program of Understanding}

Dating back to the close of the nineteenth century, early modern interpreters showed interest in the overall editorial structure of the Psalter. Both F. Delitzsch ${ }^{498}$ and Benno Jacob ${ }^{499}$ asked about the arrangement of the Psalms in the Psalter, thereby raising the issue of a purposeful editorial structure. ${ }^{500}$ While some followed up on

\footnotetext{
498 Delitzsche, The Psalms, 19-23. Note that his first edition appeared in 1859.

499 Benno Jacob, "Beiträge zu einer Einleitung in die Psalmen. IV. Die Reihenfolge der Psalmen," ZAW 18 (1898): 99-110.

500 Jean-Marie Auwers presents the observations of these two modern authors prior to the publication of $11 \mathrm{Q} 5\left(=11 \mathrm{QPS}^{\mathrm{a}}\right)$. Idem, La Composition Littéraire du Psautier un État de la Question, CahRB 46 (Paris: J. Gabalda, 2000), 15-16. (For 11Q5, see Florentino García Martínez and Eibert J. C. Tigchelaar, The Dead Sea Scrolls Study Edition, vol. 2 [Leiden, Netherlands: Brill, 1998], 1172-79.)
} 
the issue, ${ }^{501}$ the editorial structure of the Psalter failed to capture the center stage of biblical scholarship. The discovery of the Qumran Psalm manuscripts, however, has challenged scholars to reconsider its importance and examine the editorial arrangement of the Psalter. ${ }^{502}$

The current shape of the Psalter is presumably based on the MT text. As indicated, the discovery of the Qumran texts, especially 11Q5, shed light on another kind of arrangement of the Psalter in Books IV and V. Does the Qumran Psalter display another kind of purposeful composition arrangement? If so, why does it differ from the MT's, and what kinds of theological reflections result from the Qumran arrangement? ${ }^{503}$

In the 1980s, Wilson (and others) spearheaded renewed interest in the editorial structure of the Psalter as a book, generating a flourishing of publications in this

501 See Auwers, La Composition Littéraire, 16-18. Among the few scholars cited, Westermann is the most prominent. See Claus Westermann, "The Formation of the Psalter" in Praise and Lament in the Psalms, trans. Keith R. Crim and Richard N. Soulen (Atlanta, Ga: John Knox, 1981), 250-58. The article was previously published as "Zur Sammlung des Psalters,” Theologia Viatorum 8 (1961-62): 278-84.

502 It is beyond the scope of this paper to discuss how the discovery of the Qumran Psalm manuscripts made an impact on the biblical study of the Psalms. With our particular focus in mind, see Gerald H. Wilson, "The Qumran Psalms Manuscripts and the Consecutive Arrangement of Psalms in the Hebrew Psalter," CBQ 45 (1983): 377-88; cf. idem, The Editing of the Hebrew Psalter, SBLDS 76 (Chico, Calif.: Scholars, 1985), chaps. 5-6. In these publications, Wilson examines how the arrangement of the psalms in the Qumran manuscripts could shed light on the MT arrangement of the Psalter.

503 The most recent survey of the topic is by Peter W. Flint, The Dead Sea Psalms Scrolls and the Book of Psalms, STDJ 17 (Leiden, Netherlands: Brill, 1997). His focus, however, is mainly on 11Q5. The materials in $11 \mathrm{Q} 5$ raise the issue of the "order" and the "content" of the Psalter that require further, thorough treatment since they contain variations of the order of the Psalter (as compared to the MT's) and also additional compositions not found in the MT's. See Flint, Dead Sea Psalms, 7 and cf. 260-62, the content of 11Q5 in the "Appendix 4: Contents of the Psalms Scrolls by Manuscript." As a whole, Flint attempts to defend his mentor James Sanders' thesis: "Qumran Psalms Hypothesis" with some modifications (see Flint, Dead Sea Psalms, 8). Since this worthy material is extraneous to our project, we leave to others any critical evaluation of his book. 
important area of biblical scholarship..$^{504}$ Within all this publishing activity, objections are also raised. Not all scholars agree with an overall purposeful arrangement of the Psalter. Some of the dissenters advocate that intentional editing is more evident in a smaller collection or concatenation (with adjacent psalms only) but not as evident in the Psalter as a whole. For example, Whybray argues that concatenation is a more plausible theory to partially explain some features of the present shape of the Psalter, and that to argue for a final editing process is merely speculative. ${ }^{505}$ Others deny a purposeful editing of the Psalter but propose to read individual psalms sociohistorically. ${ }^{506}$

Based on the discussion above, it becomes apparent that when studying the structural arrangement of the Psalter, one of two approaches can be adopted: ${ }^{507}$ first, to limit the view by regarding certain sections - two of the adjacent psalms or a group of psalms - of the Psalter (like Whybray), and second, to expand or broaden the view by regarding the overall canonical Psalter (all 150 psalms; like Wilson). Whichever approach is adopted, several matters are left unresolved. Is it intended that the Psalter

504 This renewed interest was sparked by many of Wilson's publications following in the footsteps of his mentor, Childs. See Wilson, the Hebrew Psalter, which captures his thesis fully. Two essays provide an overview or survey of scholarly studies of the overall structure of the Psalter: (1) Norman Whybray, Reading the Psalms as a Book, JSOTSup 222 (Sheffield: Sheffield Academic Press, 1996), chaps. 1 and 2 and (2) David Howard, Jr., "Recent Trends in Psalm Study," in The Face of Old Testament Studies, 332-44. One can gain more bibliographical data in these two articles. Furthermore, where suitable in this project, helpful references will be provided. At the risk of generalization, these terms may mean the same thing (area of study): structure and message of the Psalter; editorial/editing structure or arrangement; overall structure; canonical shape; (literary/canonical) composition or arrangement; programmatic structure or understanding; and finally, the Psalter as a book. The terms "shape" and "shaping" of the Psalter deserve comment here. As Nancy L. deClaissé-Walford points out, the shape of the Psalter is after Childs and the shaping of the Psalter is after Sanders. See the bibliographical data for Childs and Sanders in deClaissé-Walford, Reading from the Beginning: The Shaping of the Hebrew Psalter (Macon, Ga: Mercer University Press, 1997), 5-6. While Sanders' "shaping" focuses on the community that shaped the formation of the Psalter, our interest aligns with Childs' final, canonical structure of the Psalter.

505 Whybray, Reading the Psalms, 121, cf. 119.

506 Erhard S. Gerstenberger, "Der Psalter als Buch und als Sammlung," in Neue Wege der Psalmenforschung: Für Walter Beyerlin, ed. Klaus Seybold and Erich Zenger (Wien: Herder, 1994), 3-13; cf. idem, Psalms: Part I, With an Introduction to Cultic Poetry, FOTL 14 (Grand Rapids, Mich.: Eerdmans, 1988), 5-22, 27-34.

507 As observed by Jerome F. D. Creach, Yahweh as Refuge and the Editing of the Hebrew Psalter, JSOTSup 217 (Sheffield: Sheffield Academic Press, 1996), 13-16. Creach sees a void in biblical studies regarding the editorial arrangement of the Psalter and has noticed that many propose a rather broad editorial structure without going into detail on how this structure can be detected in a group of psalms or in the book itself. His monograph is an attempt to fill this void by using a "wordfield" of הor ("take refuge in" in Ps 2:12) to survey how it ties together the rest of the Psalter. We will critique his thesis in our study of Psalm 2 later. 
be used for private meditation, or for public reading in worship? Is the Psalter a loosely conglomerated collection, or a purposeful configuration ${ }^{508}$

The underlying assumption for both approaches - a limited selection or the Psalter taken as a whole - is that there is a purposeful collection behind the Psalter by a (group of) redactor(s). ${ }^{509}$ For example, the Psalms of Ascents are an obvious result of the editing (or collecting) process. Another example crucial to the overall structure of the Psalter is Psalms 146-150, referred to as the Hallelujah-psalms. These smaller collections in the Psalter illustrate that there is a possibility of a purposeful editing of the Psalter. ${ }^{510}$ Since the possibility exists, an examination of the shape of the Psalter by viewing Psalms 1 and 2 as its beginning is feasible. Both psalms have been crucial to the overall understanding of the Psalter and thus may provide insights into the theological shape of the Psalter.

\subsubsection{A Programmatic Structure of the Psalter Shaped by Psalms 1 and 2}

At the onset of this study, one key issue needs to be addressed. Are Psalms 1 and 2 treated as one unit in a literary and theological sense? The answer to this question will determine how the Psalter should be read theologically. At the risk of sounding simplistic, it might be said that Psalm 1 is about the Torah and Psalm 2 is about the messianic king. If the two psalms are not regarded as one unit, and if Psalm 1 is regarded as the only introduction to the Psalter, then the implication is that the Psalter should be read similarly to the Torah. If Psalm 2 is part of the introduction, then the implication is more complex, which will be treated later in this chapter. Furthermore, from the biblical traditions, the citation in Acts 13:33 compounds the issue. While

508 These two issues are addressed by Erich Zenger, "Der Psalter als Buch," in Der Psalter in Judentum und Christentum, ed. Zenger, Herder's Biblical Studies 18 (Breisgau, Germany: Herder Freiburg, 1998), 1-35. Whybray lists seven points of agreement evidenced in scholars' views of the composition and purpose of the Psalter and adds six points of disagreement in his Reading the Psalms, 30-32.

509 Since it is impossible to verify the number of redactors for the Psalter, we will use "redactor" in the singular to represent one or many.

510 A recent and comprehensive attempt to trace the editing process of the Psalter beginning with individual psalms, moving to psalm-groups, and then to the overall compositional editing of the Psalms is the ambitious endeavor of Matthias Millard, Die Komposition des Psalters: Ein Formgeschichtlicher Ansatz, FAT 9 (Tübingen: Mohr, 1994). His thesis and methodology are critiqued by Hermann Spieckermann, "Psalmen und Psalter: Suchbewegungen des Forschens und Betens," in Perspectives in the Study of the Old Testament and Early Judaism: A Symposium in Honour of Adam S. van der Woude on the Occasion of His 70th Birthday, ed. Florentino García Martínez and Ed Noort, VTSup 78 (Leiden, Netherlands: Brill, 1998), 140-42. 
Ps 2:7 is cited there, it is called "the first psalm" by some Greek manuscripts. ${ }^{511}$ To summarize, there are basically two positions one can assume regarding Psalm 1-2 as a unit in the scholarship debate: either they should be treated as one unit or two separate units. Our position is to treat both psalms as one unit; due to space limitations, we will present the opposite view, along with our critique, in appendix 6.

\subsubsection{Psalms 1 and 2 Are One Theological Unit}

Treating Psalms 1 and 2 as one unit has its own reasons and interpretation history. Notably, the idea of treating both psalms as one unit did not originate in Christian ${ }^{512}$ but in Jewish circles, ${ }^{513}$ as Paul Maiberger specifies. Moreover, it has been pointed that both psalms have long been argued as "proömium" for the Psalter. ${ }^{514}$ Others propose the unity of Psalms 1-2 for other reasons or purposes. For example, E. Lipiński proposes that Ps 2:11-12 was at one time originally part of Psalm 1, ${ }^{515}$ though his

511 See Bruce M. Metzger, A Textual Commentary on Greek New Testament: A Companion Volume to the UBSGNT (Fourth Revised Edition), 2d ed. (Stuttgart: Deutsche Bibelgesellschaft/German Bible Society, 1994), 363-65. Cf. Ben Witherington, III, The Acts of the Apostles: A Socio-Rhetorical Commentary (Grand Rapids: Eerdmans, 1998), 412 (footnote 222).

512 Interestingly, Psalm 1 has never been quoted in the NT despite its significance in the Jewish exegetical traditions. See Dietrich-Alex Koch, "Auslegung von Psalm 1 bei Justin und im Barnabasbrief," in Neue Wege der Psalmenforschung, 225.

513 Paul Maiberger comments: "Der Brauch, die beiden ersten Psalmen als Einheit zu behandeln, stammt jedoch nicht aus christlichen, sondern aus jüdischen Kreisen.” See idem, "Das Verständis von Psalm 2 in der Septuaginta, im Targum, in Qumran, im fruhen Judentum und im Neuen Testament," in Beiträge zur Psalmenforschung: Psalm 2 und 22, ed. Josef Schreinder, FB 60 (Würzburg: Echter, 1988), 85. Later, after his survey of ancient sources and modern scholars, he comments that Psalms 1-2 should be considered as one "eng Zusammengehörig" despite the fact that they have "unterschiedlichen Herkunft und Entstehungszeit” (p. 88).

514 Delitzsch, The Psalms, 82. Delitzsch's idea has been reconsidered recently by Frank-Lothar Hossfeld and Erich Zenger, Die Psalmen I: Psalm 1-50, NechtB (Würzburg: Echter, 1993), 8. There, Hossfeld and Zenger comment: "Ps 1 und 2 als zweiteiliges Proömium des Psalters." Cf. Zenger, "Wozu tosen die Völker . . . ? Beobachtungen zur Entstehung und Theologie," in Freude and der Weisung des Herrn: Beiträge zur Theologie der Psalmen, ed. Ernst Haag and Frank-Lothar Hossfeld (Stuttgart: Katholisches Bibelwerk GmbH, 1986), 498. There, Zenger remarks that both psalms are like "eine Art Diptychon.” Zenger's "diptych” is an attempt to capture the argument forwarded by Hans Bardtke, "Erwägungen zu Psalm 1 und Psalm 2," in Symbolae Biblicae et Mesopotamicae: dedicatae Francisco Mario Theodoro de Liagre Bhöl, ed. M. A. Beek, A. A. Kampman, C. Nijland and J. Rychmans (Leiden, Netherlands: Brill, 1973), 1-18. According to Bardtke's analysis of Psalms 1-2, Psalm 1 concerns salvation directed by Yahweh to individuals through Torah-piety; while Psalm 2 concerns salvation through obedience to Yahweh's lordship directed to the people.

515 E. Lipiński, “Macarismes et Psalumes de Congratulation,” RB 75 (1968): 321-67, quoted in Zenger, "Wozu tosen die Völker," 499. It stretches beyond our scope to diachronically track the formation of these two psalms. 
suggestion is not textually verifiable and is deemed a bit extreme. From a liturgical point of view, William Brownlee suggests that Psalm 1 is "aptly joined to and knitted together with Ps 2 for the coronation of one of the kings of Judah." ${ }^{16}$ On the other hand, John Walton views Psalms 1-2 as an introduction to the Davidic Covenant from a theological-covenantal point of view ${ }^{517}$ (we will come back to this Davidic covenantal notion later in this chapter).

None of the above notions, however, have given sufficient attention to the rhetorical purpose of the juxtaposition of Psalms 1-2 in the Psalter. This omission, therefore, means a rhetorical analysis of both psalms is much needed but due to our space limitations, we opt to provide a rhetorical analysis of both Psalms in appendix 7. The effect or result of this rhetorical analysis, especially in view of the correlation of Psalm 1 and 2, is offered in the next two sections.

\subsubsection{Effect of the Rhetorical Structure of Psalm 1}

We have two comments regarding the effect of the rhetorical structure of Psalm $1 .^{518}$ First, words that signify a blessing-motif are placed strategically in the Psalter, thus creating a semantic-thematic link to some key antecedent Scripture. Psalm 1 and the Psalter begin with this word אַשְׁרי ${ }^{519}$ Its synonym, ברך, appears in strategic positions in various parts of the Psalter, that is, at the end of Books I-IV: 41:14[13], 72:19, 89:53[52],

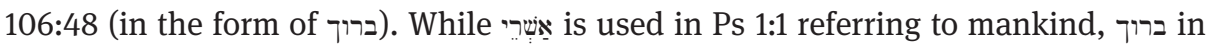
each incident cited is for the Lord ("blessed" in the sense of "praise"). Nonetheless, the blessing-motif, possibly as a frame for the Psalter, should be explored later in view of Psalm 110. This Psalm cites Gen 14:18-20, which is noticeably saturated with the same motif.

Second, while v. 6 is seemingly "out" of the chiastic structure, ${ }^{521}$ it serves as a recap of the poem and, as an important feature, points the reader back to Yahweh.

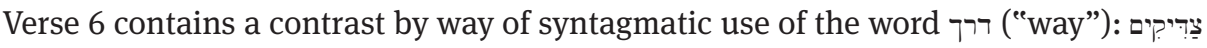

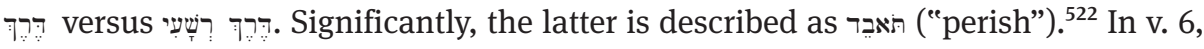
the reason for perishing is not stated explicitly but presumably the perishing is caused

516 William H. Brownlee, "Psalm 1-2 as a Coronation Liturgy," Bib 52 (1971): 332.

517 John H. Walton, "Psalms: A Cantata about the Davidic Covenant," JETS 34 (1991): 24.

518 For a rhetorical analysis of Psalm 1, please refer to appendix 7.

519 It should be rendered as "O, the blessedness of." See Michael L. Brown, "אַשְרִי, NIDOTTE, 1: 570. 520 Henri Cazelles, "אַשְרִ," TDOT 1: 445. Cf. Kraus, Psalms 1-59, trans. Hilton C. Oswald (Minneapolis, Minn.: Augsburg, 1988), 76. Both works argue that ברוך is older and belongs to liturgical use while is secular.

521 See appendix 7 for our analysis.

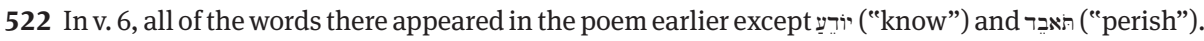
Nearly the exact phrase ודרך רשעים תאבד reappears in Ps 2:12. 
because the wicked ignore the Torah. ${ }^{523}$ According to 2:12, the picture is made clear (Psalm 2 will be explored later in this analysis): briefly, those who refuse to pay homage to the son of Yahweh will perish (cf. 2:11). Note also how in Ps 1:6a "the way of the wicked" is the subject of the verb "to perish" in v. 6a. Naturally, one would expect "the way of the righteous" to be the subject of the verb "to know," but surprisingly, that is not the case. Instead, Yahweh is the subject of the verb "to know" with the object "the way of righteous." 524 Such "inconsistency" ("the way of the wicked will perish" vs. "Yahweh knows the way of the righteous"), with the aid of the un-repeated verb "to know", ${ }^{25}$ shifts the attention back to Yahweh. This is despite the fact that Yahweh occurs only two times in the text; once in v. 6 and the other time in the phrase בתורת יהוה "Torah of Yahweh" in v. 2. The point is that the Torah of Yahweh, the object of meditation by any person, serves as a pointer to Yahweh himself. In other words, the revelatory aspect of the Torah is stressed, that the Torah reveals who God is or what his plans are. ${ }^{526}$ The rationale of the notion is to safeguard against an undue over-emphasis on the Torah as the center of Psalm 1, thereby making it a reading guide for the remainder of the Psalter, as suggested by some scholars. ${ }^{527}$

In a similar vein, some scholars see the notion of Torah as the center of or as a reading guide for the Psalter and blend the Torah with "wisdom" as a redactional

\footnotetext{
523 For example, a typical comment looks like this: "Meditation upon YHWH's instruction separates the ציקים (the righteous ones) from the רשים (the wicked ones).... Psalm 1 suggests that the way to overcome the רשעים is to delight in and meditate on the תורת יהוה." See, deClaissé-Walford, the Hebrew Psalter, 42-43.
}

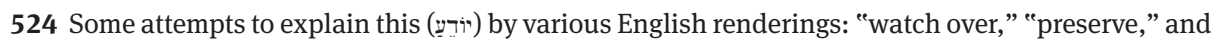
"love." See A. A. Anderson, The Books of Psalms, vol. 1, NCB (Grand Rapids, Mich.: Eerdmans, 1972), 63.

525 See footnote 31 (following); cf. footnote 32. Scholars view this psalm as a wisdom psalm partially because of this word ("he knows").

526 Cf. Moshe Greenberg, "Three Conceptions of the Torah in Hebrew Scriptures," in Die Hebräische Bibel, 378.

527 For treatment of Psalm 1 as Torah, see James L. Mays, "The Question of Context in Psalm Interpretation," in Shape and Shaping of the Psalter, ed. J. Clinton McCann, 14-20. JSOTSup 159 (Sheffield: Sheffield Academic Press, 1993), 16; cf. idem, "The Place of the Torah-Psalms in the Psalter," JBL 106 (1987): 4-5, cf. 10. Cf. Zenger and Hossfeld, Die Psalmen I, 45-46. Also see Zenger, "Der Psalter als Wegweiser und Wegbegleiter: Ps 1-2 als Proömium des Psalmenbuchs," in Sie wandern von Kraft zu Kraft: Aufbrüche, Wege, Begegungen. Festgabe für Bischof Reinhard Lettmann, ed. Arnold Angenendt and Herbert Vorgrimler (Kevelaer: Butzon and Bercker, 1993), 29-35. A modified view of Psalm 1 as Torah is proposed by Reinhard Gregor Kratz, "Die Tora Davids," ZTK 93 (1996): 1-34. In that article, Kratz views the Ps 1:2 reference to "Tora Jhwhs" as distinct from "Tora des Mose" and through the structure of the five books, frequent references to David and the ending doxologies argue for the Psalter as "Torah of David" in comparison to the Pentateuch as "Torah of Moses." 
strategy of reading the Psalter. ${ }^{528}$ The debate of Torah-Wisdom as a redactional strategy serving as a guide for reading the Psalter extends beyond our discussion. ${ }^{529}$ Suffice it to say, both conceptions equally distort the "hermeneutical point of view" that these two psalms insinuate. Both the Torah and wisdom should be regarded a (redactional) "tool" rather than the center or be considered a classification for the understanding of the psalms.

\subsubsection{The Effect of the Rhetorical Structure of Psalm 2}

For the effect (or result) of our rhetorical analysis of Psalm 2,530 four items are deserving of the reader's attention. The first noteworthy item is the observable

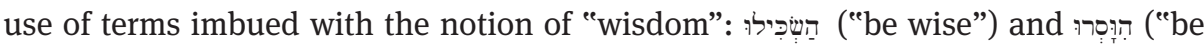
admonished") ${ }^{531}$ in v. 10. In a literary sense, these words signal to the sensitive reader a reference to Psalm 1 where there is a lexical sense of the notion of Torah-wisdom. The leaders of the nations are now charged to act prudently, that is, to serve Yahweh as stated in v. 11 .

The second noteworthy item is how deleting or retaining the phrase the son") has stimulated much discussion in biblical scholarship. Most propose to

528 For Psalm 1 as an invitation to obtain wisdom through the study of the Torah, see Gerald T. Sheppard, Wisdom as a Hermeneutical Construct: A Study in the Sapientializing of the Old Testament, BZAW 151 (Berlin: Walter de Gruyter, 1980), 142.

529 It can be traced back to Westermann, who proposes that Psalm 1 and 119 form the beginning and ending frame for an early collection of a Psalter. See idem, "Formation of the Psalter," 253. Cf. Joseph Reindl, "Weisheitliche Bearbeitung von Psalemen: Ein Beitrag zum Verständnis der Sammlung des psalters," in VTSup 32 (Leiden: Brill, 1981), 333-56. In this article, Reindl proposes "wisdom" as endredaction by looking at Psalms 1 and 146-50, and also by seeing an example in Psalms 90-92 in their shared vocabulary and theme. The argument of Torah-wisdom redaction shaping the Psalter may become too crucial to be dismissed when we come to Book V, where the massive Psalm 119 has been regarded by some as the "center" of Book V. We will further explore the topic in our study of Book V in our next chapter.

530 For a rhetorical analysis of Psalm 2, see appendix 7.

531 Scholars have noted the wisdom influence on Psalm 2 based on these two words. For the former, see Terence Fretheim, "שכל," NIDOTTE, 3: 1243; for the latter, see M. Saebo, "סרי," TLOT, 2: 549. See the wisdom notion noted by E. Beaucamp, Le Psautier: Ps 1-72, SB (Paris: Gabalda, 1976), 46 when he comments on vv. 10-12. 
emend or delete $i^{532}$ but not one of these proposals, in our opinion, is legitimate and satisfactory. Although the LXX has a different reading $\delta \rho \alpha \xi^{\prime} \alpha \sigma \theta \epsilon \pi \alpha\left\llcorner\delta \in \epsilon^{\prime} \alpha \varsigma\right.$, " take hold of discipline," ${ }^{333}$ something must be in the MT that the LXX translator either could not make any sense of, or he might have rendered a different Hebrew text not passed along to us. Carsten Vang, with his poetic-structural approach, in our opinion, argues very convincingly that each strophe of Psalm 2 contains all of these three characters: Yahweh, the messianic king, and the pagan kings. To delete this phrase would "therefore be very peculiar" 534 and throw off the balance.

There is a progression leading to this phrase syntagmatically: from the designation of this person as "the messiah," to becoming "king" [of Yahweh], to being called "son" [of Yahweh], then to being "son" (בר) again (see vv. 2, 6, 7 and 12). ${ }^{535}$ The Aramaic word "בֵ "son," contained in v. 12, not only continues the theological progression but also implies having a wider audience - namely the nations - in view. ${ }^{536}$ As a result, the messianic king as the divine son will rule from Zion extending to a wider (worldwide) area.

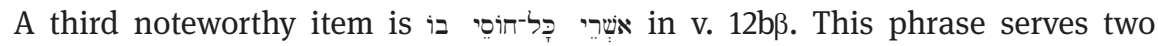
functions, one literary and one theological. In the literary function, it serves as an

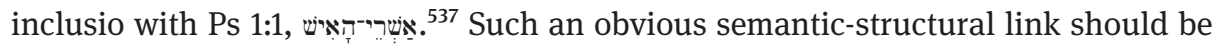
beyond any doubt; any scholar denying this link has given little thought to the

532 See BHS. Julian Morgenstern, "נשקו בר, J JQR 32 (1941-42): 371-85. His article, after surveying the history of the interpretation of this phrase, proposes to emend it as תנו לשמו כבד "rendering honor to [Yahweh's name]" (p. 384) but deletes the whole phrase in his reconstructed Hebrew text (p. 382). Such emendation (deletion) and reconstruction cannot be justified textually. For the best and most detailed evaluation of the textual matter of this phrase, see Peter C. Craigie, Psalms 1-50, WBC, vol. 19 (Waco, Tex.: Word Books, 1983), 64. Cf. G. E. Closen, "gendanken zur Textkritik von Ps 2,11b + 12a," Bib 21 (1940): 288-309. There he examines three proposals: the MT, "Schreibweise vor der Verlesung," and the "original" (ונשקו לרגליו ברערה), based on A. Bertholet's two articles: "Eine crux interpretum. Ps 211f," ZAW 28 (1908): $58-59$ and "Nochmals zu Ps 2:11f," ZAW 28 (1908): 193. He accepts the third proposal, and many scholars who follow him also hold to the same view.

533 See Schaper, The Greek Psalter, 74-75; he analyzes this phrase in light of extra-biblical material. 534 Carsten Vang, "Ps 2, 11-12 - A New Look at an Old Crux Interpretum," SJOT 9 (1995): 178. In our judgment, Vang's article provides the most convincing defense of retaining the MT reading for v. 12 .

535 Ibid., 180. Note how Vang does not view it from a discourse analysis point of view.

536 One should not be surprised to find Aramaic words in the Hebrew Bible. See portions of Daniel and Jer 10:11. For the latter reference, this Aramaic verse is used to address the nations; see 10:10. Therefore, we should (1) retain the MT phrase as such and (2) reject some scholars who deny the universal (wider sense) dominion implicated by this Psalm (see for example, David J. A. Clines, "Universal Dominion in Psalm 2?" in On the Way to Postmodernism: Old Testament Essays, 1967-1998, ed. Clines, vol. 2 [Sheffield: Sheffield Academic Press, 1998], 701-707).

537 On a larger scale (beyond Psalms 1-2), the word plays a literary structural role for the Psalter. See Jacob, "Reihenfolge der Psalmen," 110-14. 
redactional intention of the Psalter. ${ }^{538}$ Its literary function is imbued with a theological notion, which will be explored at greater length in the next section.

The fourth noteworthy item is the phrase in the clause כָכליחוֹטי בו that requires identifying who it is in whom all should take refuge. Syntactically, the closest antecedent is בר "son" whether the speaker of this verse is Yahweh (being quoted by the messianic king) or the poet himself. ${ }^{539}$ As a result, the admonition that begins in v. 10 serves to urge kings and leaders of nations to take refuge or put their trust $(\mathrm{n} \text { (1) })^{540}$ in the "son," the messianic king, syntagmatically portrayed earlier in Psalm 2. ${ }^{541}$

Based on the above effect and result of our rhetorical analysis, we now delineate the interaction of Psalms 1 and 2 as the programmatic introduction to the Psalter.

\subsubsection{A Theological Interaction of Psalms 1-2: Shaping the Reading of the Psalter}

We now consider how these two psalms should be read interactively, and as a consequence, how they both shape the way the Psalter is to be read. In our judgment, most scholars who favor reading Psalm 1 as the introduction of the Psalter will advocate that Psalm 1 should shape the reading of the Psalter, including the reading

538 The redactional intention can be seen in these semantic links between Psalms 1 and 2: אשרי, אבד, דרך, שפט, , ים , התן, (and Yahweh).

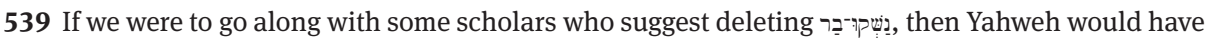
been the object of $i$, cf. v. 11.

540 Though non is commonly glossed as "take refuge in," it became "a formula of trust in the songs of lament or confidence." See E. Gerstenberger, "הon," TLOT, 2: 465. Cf. how the LXX renders this Hebrew

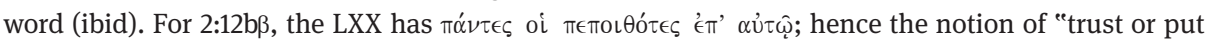
confidence in" is explicated here.

541 If the son is who refers to, some scholars may challenge our interpretation in view of the

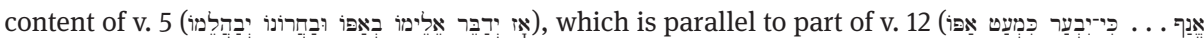
(פְ); clearly in v. 5, the anger comes from Yahweh, not the messianic king. Our response is that "who"

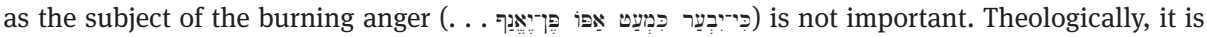
feasible to have either Yahweh or his messianic king be angry. The key is "who" (בו) is the person in whom they take refuge in v. 12bß Syntactically and syntagmatically, בו can only be identified with the "son" בר. Creach delineates his thesis that the editing of the Psalter can be traced to or nearly be based on 2:12bß. See idem, Yahweh as Refuge, 17-18. Unfortunately he does not exegete Psalm 2, and therefore mistakenly identifies Yahweh as the object of בו Such distinction (Yahweh vs. Yahweh's messianic king/son) may not be significant theologically. In fact, Yahweh as refuge is not uncommon in the OT (cf. Ps 5:12[11]). Yet exegetically, we need to maintain this distinction in order to be fair to the text. If our exegesis is correct, this could be detrimental to Creach's entire thesis. In addition, part of his argument in chap. 3 is the Torah "as a surrogate for Yahweh's refuge" is unconvincing and even he himself admits that neither does the "Torah as refuge" occur in the OT, nor has the verb "take refuge" ever taken the Torah as its object (p. 72). He also admits that using "Yahweh as refuge" to trace the editing of the Psalter encounters massive difficulty in Book V (p. 104). 
of Psalm 2. ${ }^{542}$ Furthermore, scholars who refuse to read Psalm 2 messianically will naturally find rapport with those sharing a similar position. ${ }^{543}$

Other scholars, classified as follows, adopt a moderate position that emphasizes Psalm 1 as a reading guide. First, J. Clinton McCann proposes to read Psalm 1 as a call for readers to appropriate the Psalter as instruction and to read Psalm 2 as the content of that instruction, that is, the Lord reigns. ${ }^{544}$ Second, Erich Zenger proposes that the king should be a Torah-reader before his people and that "Die sich in der Psalmenrezitation vollziehende Aneigung der Tora JHWHs ist der konkrete Vollzug von מהוה "545 Third, Patrick D. Miller's thesis claims that the voice of the king/the anointed in Psalm 2, who in later psalms (Psalm 3 and following) is represented by David in various psalms' superscriptions, ${ }^{546}$ is also the voice of the one who reads and lives by the Torah. ${ }^{547}$ To a certain degree, all of these positions favor Psalm 1 as the basis for shaping the reading of Psalm 2 and thus of the Psalter.

We suggest, however, that there is a syntagmatic progression from Psalm 1 to Psalm 2 based on semantic links between the two and consequently, Psalm 2 shapes

542 Wilson's position on Psalm 2 is noteworthy. Since he regards Psalm 1 as the introduction to the Psalter, he looks at Psalm 2 as an introduction to Book I with the theme "dominated by royal considerations and especially the institution of the Davidic covenant (cf. 2 Sam 7:14ff)." Idem, "The Use of Royal Psalms at the 'Seams' of the Hebrew Psalter," JSOT 35 (1986): 85-94, reprint, The Poetical Book, ed. David J. A. Clines, The Biblical Seminar 41 (Sheffield: Sheffield Academic Press, 1997$), 77$. (Pagination is according to the reprint.)

543 Reading Psalm 2 messianically is not a welcome proposition in critical scholarship. Under the form- and historical-critical method, as Deissler points out, the question being asked is "In welchem Sinne ist Ps 2 'messianisch'?" See Alfons Deissler, "Zum Problem der Messianität von Psalm 2," in De la Törah au Messie, 283-92. We have witnessed how some key verses with messianic overtones in Psalm 2 are being truncated: J. Alberto Soggin, "Zum zweiten psalm,” in Wort-Gebot-Glaube: Beiträge zur Theologie des Alten Testament. Walther Eichrodt zum 80. Geburtstag, ed. J. Stamm, E. Jenni and H. Stoebe (Zürich: Zwingli, 1970), 191-207; Isaiah Sonne, "The Second Psalm," in HUCA 19 (1945-46): 50-54; Bardtke, "Erwägungen zu Psalm 1"; and Morgenstern, "נשקי ברו." Diedrich argues for a nonmessianic reading in that Psalm 2 is an exhortation for the reading community of the Psalter. Idem, "Psalm 2: Überlegungen zur Endgestalt des Psalms," in Beiträge zur Psalmenforschung," 62-64.

544 J. Clinton McCann, Jr., A Theological Introduction to the Book of Psalms: The Psalms as Torah (Nashville, Tenn.: Abingdon, 1993), 41. Mays holds a similar position ("Place of Torah-Psalms," 10).

545 Erich Zenger, "Der Psalter als Buch,” 38 (italics his); read also 36-37.

546 For a discussion of the nature and types of psalm superscription, see S. E. Gillingham, The Poems and Psalms of the Hebrew Bible (Oxford: Oxford University Press, 1994), 245-51.

547 Patrick D. Miller, "The Beginning of the Psalter," in Shape and Shaping, 91-92. Similarly by Brownlee, "Coronation Liturgy," 332: that the man in Psalm 1 who reads the Torah is the ideal king in Psalm 2 based on Deut 17:18-20. 
Psalm 1 in our proposal. ${ }^{548}$ There are three elements we observe in these two psalms to support our notion.

First, there is a shift of the focus from the Torah to the messianic son based on the syntagmatic use of this keyword אשרי. Clearly, the one whose delight is in the Torah

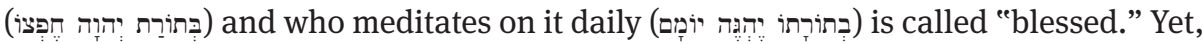
since Psalm 1 is redactionally placed with Psalm 2, such placement probably intends to help any Psalm reader - by repeating the word אשרי 2:12 - move from the TorahFrömmigkeit to another category of blessing, which is for those who take refuge in the "messianic king and son." " Here the tone is positive. In the next element, however, the tone is negative.

Second, Ps 2:12 refines the notion of who will perish in Ps 1:6. According to 2:12, those who refuse to "kiss the son" or "take refuge in him" provoke divine wrath, with

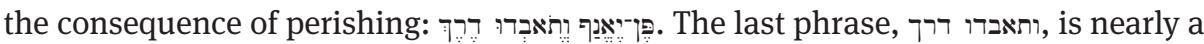

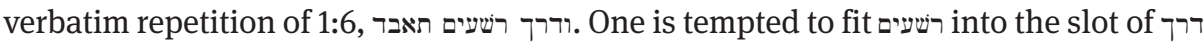
but the redactor refines or confines who is going to perish by the rest of Ps 2:1112. In no uncertain terms, the ones who refuse to kiss the son, and those who refuse to serve Yahweh, ${ }^{550}$ will perish. Note also how 2:1 and 2:2 have already alluded to those

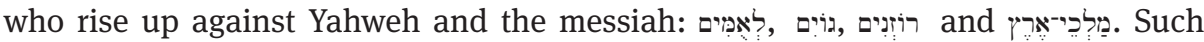
understanding is a marked departure from Psalm 1 where, in contrast, the reason for "the perishing of the wicked" is rather ambiguous. We can probably postulate that the placement of Psalm 1 followed by 2 is to define the wicked (and the consequence of one's wickedness) not so much by his relationship with the Torah, but by his relationship with Yahweh or his messianic son. A question that naturally follows is what is the role of the Torah in Psalm 1 in relation to Psalm 2? Our next point offers an explanation.

Third, the wisdom link between Psalms 1-2 by these three words

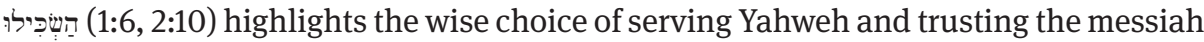
stemming from the reading of the Torah. A challenge is presented to the kings and the

548 A recent work by Robert L. Cole has taken the interaction of Psalms 1-2 seriously. By noting the person in Psalm 1 as royal and priestly figure, the same person reappears in Psalm 2 as heavenly priestly king. See his, Psalms 1-2: Gateway to the Psalter. Hebrew Bible Monographs 37 (Sheffield: Sheffield Phoenix Press, 2013). How his work differs from mine is further explained in the following paragraphs.

549 In discourse analysis, the syntagmatic dimension is helpful here. In a syntagmatic study of a word like אשרי a primary task is to determine how it is collocated with other words. Not taking a syntagmatic view, Barbiero arrives at a similar conclusion: "Inhaltlich sind die beiden Seligpreisungen, Ps 1,1 und

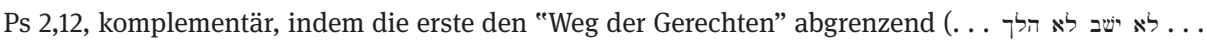
und die zweite diesen positiv (לא עמר (הסה ב) darstellt." Idem, Das Erste Psalmenbuch als Einheit: Eine Synchrone Analyse von Psalm 1-41, OBS 16 (Frankfurt: Peter Lang, 1999), 37.

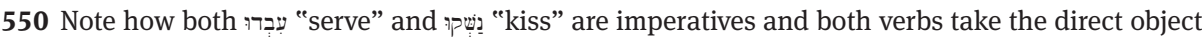
of divinity, Yahweh and his son respectively. 
rulers of the earth: they should "be wise" (השְּׁילוּ) so that they serve Yahweh, kiss the son, and put their trust in him (vv. 11-12). The challenge can only be met when they do what Psalm 1 has hinted at through the notion of wisdom, particularly in v. 6a. Verse $6 \mathrm{a}$ is crucial in two aspects. As noted earlier, v. $6 \mathrm{a}$ is a recap of vv. 1-3. ${ }^{551}$ In these three verses, the center is v. 2, sandwiched by (1) the negative notions of the "wicked" in v. 1 and (2) a tree-simile of the righteous in v. 3. The theme of v. 2 is plain: the delight and the meditation of the Torah. Syntagmatically, יהוה only occurs in v. 6 and v. 2. In the latter reference, יהוה is collocated with the Torah. Through these collocations and the hint of wisdom, we then can conclude that the kings and rulers of the nations could be prudent if and when they read the Torah. Since 2:10 has a literary tie with vv. 11-12 as one strophe, we can also infer that the reading of the Torah helps the kings to make a wise choice, the wise choice being to serve (עיבְר) Yahweh and to pay homage

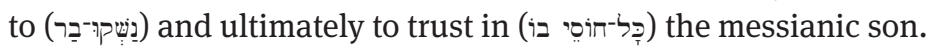

To conclude, Psalm 2 seems to shape how we read both Psalm 1 and the Psalter as a whole from a redactional view. ${ }^{552}$ The import of meditation on the Torah evidenced in Psalm 1 - Psalm 2 is through the wisdom redactional link. As a result, the revelatory aspect of the Torah is properly stressed, namely, that the Torah ultimately points to trusting in Yahweh's messiah. Psalm 2, on the other hand, redefines or qualifies the "blessedness" of Psalm 1 by linking it to the messianic king. It does not contradict Psalm 1's Torah-induced blessedness if we interpret it the way we propose. Consequently, through our syntagmatic and poetic analysis, it becomes evident that there is a mutual or reciprocal relationship between the Torah and the messianic king through the interaction of these two psalms. Our position differs from other scholars' whose view, though similar, is not identical to ours. To explain the viewpoint difference, we would say that most see the Torah-kingship in the interaction of Psalms $1-2 .{ }^{553}$ Our viewpoint, perhaps more refined by our rhetorical study of Psalms 1-2, is that the revelation of the Torah points to trusting in the messiah of Yahweh, whose kingship and sonship are both affirmed in Psalm 2. ${ }^{554}$ Thus, we do not deny but deeply affirm Yahweh's kingship; in fact, we qualify it further in view of our study of Psalms 1-2, namely, the messianic kingship of Yahweh.

551 See appendix 7 (our chiastic analysis for Psalm 1: vv. 1-3 as AA', vv. 4-5 as B'B in footenote). 552 See Bernd Janowski, “Die 'Kleine Biblia': Zur Bedeutung der Psalmen für eine Theologie des Alten Testaments," in Der Psalter in Judentum und Christentum, 408-409. There he remarks: "Die redaktionelle Inclusio von Ps 1-2 transformiert dementsprechend in Ps 2,12b den seliggepriesenen 'Gerechten' von Ps 1,1 in 'alle', die auf JHWH vertrauen.” For us, to be more specific as dictated by our analysis, the last phrase of Janowski should be "die auf Gesalbten vertrauen."

553 For examples, see Miller, "Kingship, Torah Obedience, and Prayer: The Theology of Psalm 15-24," in Neue Wege der Psalmenforschung, 127-42.

554 The author of Hebrews may have noted these two notions, kingship and sonship, when he quotes this psalm in his composition. See chapters ten and eleven of this project for further discussion. 
Earlier we had alluded to the Davidic covenant in Psalm 2, which is a prominent feature we cannot afford to ignore. In our understanding of the programmatic introduction set out in Psalm 1-2, Psalm 2 should be viewed from the Davidic covenant, despite the absence of the term in the psalm. ${ }^{555}$ Presumably adopting a Davidic covenantal perspective, various scholars have linked together psalms like Psalms 72 (Book II), 89 (in Book III), 110 and 132 (in Book V). ${ }^{556}$ Therefore, we will bear in mind the Davidic covenantal perspective as we investigate the structure of the Psalter. ${ }^{557}$

In our study thus far a notion has emerged, namely, Torah-revelation-(Pointing-) to-Trusting-Messiah. The test question is, can we sustain this notion throughout the remainder of the Psalter ${ }^{558}$ We propose, due to the limitations of this project, to

555 Wilson comments: "Thematically, Psalm 2 is dominated by royal considerations and especially the institution of the Davidic covenant (cf. 2 Sam 7). The psalm throughout presents a positive evaluation of the Davidic covenant divinely instituted and that continues to experience divine support. As such the psalm is admirably fitted for its function as the introduction of the highly Davidic collection of psalms which follows." Idem, "Use of Royal Psalms," 77.

556 For example, Starbuck argues for four oracular royal psalms, Psalms 2, 89, 110 and 132, among which Psalms 89 and 132 overtly mention the Davidic covenant while Psalm 2 and 110 do not (Court Oracles, 142, cf. 122-68).

557 Under the Davidic covenantal framework, David (as a figure) and the Davidic psalms are viewed in an eschatological sense. For example, the Davidic psalm-groups, according to Deissler, is an anticipation of the coming of the last David; see idem, "Die Stellung von Psalm 2 im Psalter: Folgen für die Auslegung," in Beiträge zur Psalmenforschung, 76, cf. 80.

558 Bruce K. Waltke proposed a four-stage canonical process for the Psalter. See idem, "A Canonical Process Approach to the Psalms," in Tradition and Testament: Essays in Honor of Charles Lee Feinberg, ed. John and Paul Feinberg (Chicago: Moody, 1981), 3-18. We summarize his proposal as follows: (1) as a result of Gunkel's form analysis, "in the original composition the king is the human subject of the psalms, whether they be lament, acknowledgement, praise, or belonging to various other types of psalms" (p. 12); (2) many types of psalms "composed for the first temple and used in it and constituting a part of Israel's canonical literature had a messianic meaning and significance that none of David's successors satisfied up to the time" of exile (p. 14); (3) in the third stage of the canonical development of the Psalter, "the psalms continued to have a royal and messianic significance, but they now carried a predictive meaning as well. Israel must now wait in hope for a future son of David worthy to pray to and sing these psalms" (p. 16); and (4) the coming of Jesus Christ has satisfied this hope; thus "within the literary context of the New Testament the psalms find their final and full meaning and perception. From this fourth and highest vantage point we win the full significance of the psalms" (p. 16). For the present study, our interest falls within the second through the fourth stage of the canonical process of the Psalter in Waltke's schema. 
examine Books I-III, ${ }^{559}$ with special reference to Psalms 72 and 89, noting how they are strategically positioned in the Psalter, and noting also the predominance of their genre as royal psalms. Then we will examine Book IV to see whether or not the messianic reading exists in the remainder of the Psalter. ${ }^{560}$

\subsection{A Study of Books I-II: With Special Reference to Psalm 72 in View of the Editorial Introduction of Psalms 1-2}

Underscored at the onset of this study are two questions: first, why should Books I and II be treated together? Second, why is Psalm 41 - the last Psalm in Book I not treated in this section when we do treat Psalm 72, which likewise serves as the end-psalm of Book II? Our two-fold response is straightforward. First, Psalm 41 is not a royal psalm; the genre of this psalm is a mixture of individual thanksgiving and lament. ${ }^{561}$ In contrast, Psalms 72 and 89 - strategically positioned as the end-psalms of Book II and III respectively - are both royal psalms. ${ }^{562}$ Second, regarding Book I and II in view of Psalm 41, we are indebted to Wilson, whose insights are worthy of full-length quotation:

\footnotetext{
559 Scholars have generally demonstrated that the binding of the first three Books (I-III) is obvious regardless how one interprets Psalms 1-2. More evident is how Psalms 1-2 bind with Book I. See, for examples, Creach, Yahweh as Refuge; Janowski, "Die 'Kleine Biblia'," 386-87 and Barbiero, Das erste Psalmenbuch. For Books I-III, see Wilson, the Hebrew Psalter; idem, "Shaping the Psalter: A Consideration of Editorial Linkage in the Book of Psalms," in Shape and Shaping, 76-78. Wilson points out that the key editorial principles for Books I-III are: "authorship" (found in the superscriptions of most of the psalms) and "genre." Idem, "Evidence of Editorial Divisions in the Hebrew Psalter," VT 34 (1984): 337-52. Moreover, see McCann, "Books I-III and the Editorial Purpose of the Hebrew Psalter," in Shape and Shaping, 93-107; cf. Zenger, "Wozu tosen die Völker," 495.

560 It is prudent to devote one chapter to study Book V where Psalm 110 is placed since Book V is the most challenging one in terms of structure. As noted by Michael D. Goulder, Book V, by the number of psalms, is the longest unit of the Psalter; he also notes there are three places where the LXX and the MT divides the psalms differently. Goulder, The Psalms of the Return (Book V, Psalms 107-150): Studies in the Psalter, IV, JSOTSup 258 (Sheffield: Sheffield Academic Press, 1998), 14. Thus the task of examining Book $\mathrm{V}$ is reserved for the following chapter. There are only a limited number of Torah psalms in the Psalter (Psalms 1, 19 and 119). Therefore, instead of tracing our notion "Torah-revealingmessiah," we limit our study by tracing the messianic reading of the Psalter. Nonetheless, when we come to Book V, we will examine it in view of our original notion ("Torah-revealing-messiah") because of the presence of Psalm 119.
}

561 Craigie, Psalms 1-50, 319.

562 See Whybray, Reading the Psalms, chap. 3; there Whybray deals with the royal Psalms 2, 18, 45, 72, 89, 110 and 132. Nonetheless, in his conclusion, he singles out Psalms, 2, 72 and 89 because of their "prominent positions which support the notion of an orientation along messianic lines" (p. 99). 
It is clear that Psalm 41, which concludes the first book, is not normally identified as one of the 'royal' psalms. While this psalm is traditionally associated with David (see the superscript), and some still attempt to connect it with events in the life of the king ..., it evidences no distinctly 'kingly' theme. ... Perhaps, a better explanation for the absence of a royal psalm at the end of Book One and Two into a single Davidic collection (a movement marked by the postscript in Ps 72:20, 'The prayers of David son of Jesse are ended') had already taken place when these royal psalms were set in their present positions. As a result, we are left with two major blocks of material (Psalms 2-72, 73-89) which are marked at their 'seams' by royal psalms. ${ }^{563}$

Given the position of Book I and II as "one" collection, ${ }^{564}$ we now turn our attention to Psalm 72, choosing as our focus the beginning and end of this Psalm. The superscription לִשל לימהה, appears to take on further meaning besides unique, ${ }^{565}$ such as "by," "to," "for," or "concerning" Solomon. While the superscription may indicate

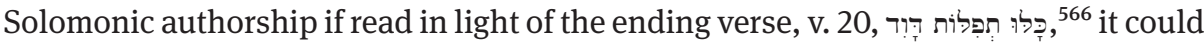
also indicate that it is a prayer of David concerning his son Solomon. The difficulty of this notion (David praying for his son Solomon), however, is the allusion to the events in 1 Kings during Solomon's reign. For example, Ps 72:10-11 seems to allude to the events in 1 Kings 5:15-26[5:1-12], 9:10-14 and 10:1-13. ${ }^{567}$ Therefore, unless David as a prophet ${ }^{568}$ foresees the events happening in Solomon's time, we should treat לשישלמה as an indication of authorship similar to the function of other superscriptions - the most noticeable one being לדִָ לחיד - in the Psalter. ${ }^{569}$

563 Wilson, "Use of Royal Psalms," 76. Wilson then discusses Psalms 2, 72 and 89 immediately after his remarks quoted above (see pp. 77-81).

564 Cf. Rolf Rendtorff who calls Books I-II the "central section ends with the royal psalm 72." Idem, The Old Testament: An Introduction, trans. John Bowden (Philadelphia: Fortress, 1986), 248.

565 This superscription is only found here and in Psalm 127.

566 Ps 72:20 is often regarded as a concluding comment for Books I and II. See Wilson, "Use of Royal Psalms," 78. Goulder views this verse as restricted to Book II; Goulder, The Prayers of David (Psalms 51-72): Studies in the Psalter II, JSOTSup 102 (Sheffield: JSOT Press, 1990), 12. In our opinion, as rightly indicated by Tate, this verse may also serve as an end of the prayer uttered in the body of Psalm 72 . See Tate, Psalm 51-100, 222-23, cf. 225. Note how Tate regards vv. $18-20$ as a concluding note only for Book II (see p. 225).

567 The Scriptural references are taken from Frank-Lothar Hossfeld and Erich Zenger, Psalmen 51100, HTKAT (Wien: Herder, 2000), 317. They appear to agree with Tate that in Psalm 72 David is praying for Solomon (see above footnote).

568 According to David C. Mitchell, in early Jewish and rabbinic writings, David is viewed as an "eschatological prophet," leading to interpreting the Psalter messianically and eschatologically. Mitchell, The Message of the Psalter: An Eschatological Programme in the Book of Psalms, JSOTSup 252 (Sheffield: Sheffield Academic Press, 1997), 31-32.

569 The Davidic superscription is the subject of our investigation in our next chapter (nine). See Wilson, The Hebrew Psalter, 155; cf. Bruce K. Waltke, "Canonical Process Approach,” 10-11. 
If Solomon is the author of this psalm, then the prayer in this psalm concerns a $k i n g^{570}$ who, in a variety of ways, is prefigured by Solomon, and whose life - or at least some aspects of or events in his life - is alluded to in this psalm. ${ }^{571}$ Who is this king? The answer is found in the strategic position of Psalm 72 itself, aided by the remark in v. 20 that concludes Books I and II. Thus, readers are clued to go back to the messianic king in Psalm 2. ${ }^{572}$ Evidenced in these two psalms are striking verbal parallels. One clear example is sufficient: linking together Psalms 2 and 72 to positively identify the king in Psalm 72 as the messianic king in Psalm 2 (compare the following):

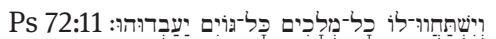

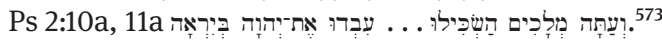

Another clue to the identity of this king is found in 72:1. The phrase לבן־מלך should not be strictly limited to Solomon ${ }^{574}$ but rather should be expanded to include the identity of someone who might be "the heir to the throne in a wider sense, the descendant in the dynasty of David." 575 Considering this phrase in light of Ps 2:6-7, it is safe to propose that the messianic son-king notion evidenced in Psalm 2 is being reiterated here in $72: 1 .^{576}$

To summarize, Psalm 72 appears to repeat the messianic kingship notion detected in Psalm 2: the programmatic reading established by Psalm 2 in the beginning of the

570 Cf. Sailhamer, NIV Compact Bible Commentary (Grand Rapids, Mich.: Zondervan, 1994), 330-31. 571 Besides Ps 72:10-11 as allusion to 1 Kings 5:15-26[5:1-12], 9:10-14 and 10:1-13, consult Hossfeld and Zenger, Psalmen 51-100, 317 for another part of Psalm 72 alluding to various events in Solomon's life in 1 Kings.

572 See Whybray, Reading the Psalms, 92.

573 One other significant parallel between Psalms 2 and 72 is 2:8 and 72:8. Tate sees the continuity and discontinuity between the two psalms. He comments: "This psalm [72] focuses not on the relationship between the king and God, such as we find in Psalm 2, but on the relationship between the king and the people with glimpses of the response of the nations and of the land itself to the reign of this royal son." Tate, Psalms 51-100, 222.

574 See deClaissé-Walford, Reading from the Beginning, 72: not only Solomon's successes but also his failures are noted by psalm readers.

575 Hans-Joachim Kraus, Psalms 60-150, 76. Cf. Tate, Psalms 51-100, 220 (note 1c).

576 We postpone a discussion of the element of the Davidic covenant here because it is more fitting to talk about it when/after we study Psalm 89. 
Psalter resurfaces at the end of Books I-II. ${ }^{577}$ Our next task, therefore, is to continue to trace this reading in Book III.

\subsection{A Study of Book III: With Special Reference to Psalm 89 in View of the Editorial Introduction of Psalms 1-2}

Book III is a collection that, according to McCann's analysis, contains "an alternation of expressions of lament and expressions of hope."578 The absence of Davidic superscription is noticeable, ${ }^{579}$ suggesting that the lament portion of this collection deals with the notion of the failure of the Davidic covenant (or more specifically, the projecting Exile for the southern kingdom). ${ }^{580}$ There are, however, indications of hope in this collection, as illustrated by Psalm 75,78 , and $84 .{ }^{581}$ As the last psalm of Book III, Psalm $89^{582}$ effectively recaps the lament-hope notion evidenced throughout the entire collection.

Some scholars, ${ }^{583}$ whose reading is based on the Psalm/Psalter's literary genre, view Psalm 89 as basically composed of three parts: vv. 1-17[1-18], vv. 18-38[19-37] and vv. 39-52[38-51], with v. 53[52] as an editorial remark (doxology) ${ }^{584}$ closing Book III.

577 How we view the superscription of this psalm (72) may not be important, be it Solomonic authorship or David's prayer for Solomon. According to VanGemeren, both David and Solomon are viewed by the writers of Scripture who look back at the times of the reign of David-Solomon "as a model describing the glories of the messianic age. From [the NT] perspective after the coming of our Lord Jesus Christ, David may seem to be only a faint reflection of the true Messiah.” Nonetheless, VanGemeren's comment, in a sense, affirms our notion of the messianic reading of the superscription, be it Solomonic (as in Psalm 72) or Davidic as in most of the Psalter. VanGemeren, Progress of Redemption, 213, cf. 233-35.

578 See the table of such alternation in McCann, "Books I-III," 97.

579 Only Psalm 86 contains a Davidic superscription (while all psalms in Book I are "Davidic" and 18 out of 32 are "Davidic" in Book II). See deClaissé-Walford, Reading from the Beginning, 73.

580 Wilson, "Use of Royal Psalms," 79; cf. idem, the Hebrew Psalter, 209-16. Some, like Robert L. Cole, propose that already beginning in Psalm 73, "a dialogue consisting of lament over the nonfulfillment of the Davidic covenant as enunciated in Psalm 72 and corresponding divine answers dominates the collection." Cole, The Shape and Message of Book III (Psalms 73-89), JSOTSup 307 (Sheffield: Sheffield Academic Press, 2000), 14.

581 See McCann, "Books I-III," 97 for more of this type of psalms in Book III.

582 See chapter six, footnote 6 for bibliographical references regarding the study of Psalm 89. See our discussion of the relationship of Psalm 89 to 2 Samuel 7 and 1 Chronicles 17 also in chapter 6. Cole has done an excellent analysis of the verbal parallels (similarities) of Psalm 89 internally and with the rest of the psalms in Book III. Idem, Message of Book III, 177-230.

583 For example, Craig C. Broyles, Psalms, NIBC vol. 11 (Peabody, Mass.: Hendrickson Publisher, 1999), 355. For him, the first section contains "a hymn" and second section "a prophetic oracle" and third "a lament".

584 See Auwers, La Composition Littéraire, 78-79 for a layout of all doxologies in the Psalter. 
The first and second parts mainly recall the elements of the Davidic covenant in 2 Samuel 7: vv. 4-5[3-4] and 20-38[19-37]; ${ }^{585}$ the turning point or segue into the third part

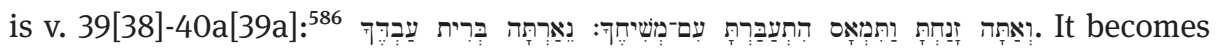
conspicuous, following this pivotal point, that "Yahweh is depicted as rejecting his anointed king and renouncing the Davidic covenant." 587

How does this psalm factor into our messianic reading of the Psalter? Obviously, the connection is in the word "messiah"588 found in vv. 39[38] and 52[51] (cf. v. 21[20]). What Psalm 89 seems to address is not the messianic king and his dominion; instead, it looks at the historical Davidic kingdom ${ }^{589}$ based on the reading of vv. 39[38] and

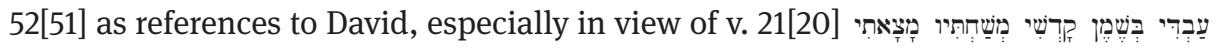
דרוּ. Therefore, when the Davidic kingdom fails, the poet poses two questions in vv. 47[46] and 50[49].

These rhetorical questions, especially the question in v. 50[49], seem to be left

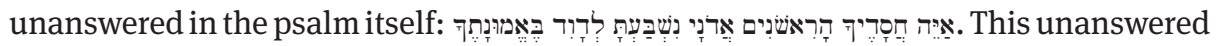
question, however, may deliberately serve as a lead-in to the study of Book IV. Interestingly, various scholars point out that Book IV itself (and some include

585 Tate, Psalms 51-100, 413; cf. Kraus, Psalms 60-150, 207-10. Mitchell highlights the "inviolable" nature of the Davidic covenant in vv. 20-38[19-37]: "Particular emphasis is placed on the eternal nature

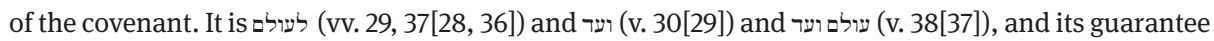
is said by Yahweh three times to be his own and (vv. 25, 29, 34[24, 28, 33]), leading to a covenant that will never be broken (v. 35[34]), confirmed by an oath sworn by Yahweh's own holiness (v. 36[35])." Mitchell, Message of the Psalter, 254.

586 Tate remarks that such an abrupt change of mood is hardly anticipated by the readers. Idem, Psalms 51-100, 427(furthermore, Tate sees vv. 39-46[40-45] as a reversal of what Yahweh has promised in the Davidic covenant in vv. 14-28[13-27]).

587 Wilson, "Use of Royal Psalms," 80. Moreover, Wilson regards Psalm 89 as "a covenant failed" (italics his).

588 Besides Ps 89:39[38] and 52[51], the Hebrew word מִָּ "messiah" occurs in the Psalter as follows: 2:2, 18:51[50], 20:7[6], 28:8, 84:10[9], 105:15, 132:10, 17.

589 Yet it should be noted that the depiction of Yahweh's kingdom and David's in this psalm are indistinguishable from each other. The latter is in total dependence on the former. See Cole, Message of Book III, 215-16. Nonetheless, the annulment of the historical Davidic kingdom does not mean Yahweh and the kingdom of his messianic son will suffer the same fate. This perspective should be kept in mind especially when we talk about the notion of Yahweh kingship in Book IV (later in this chapter). For an exposition of the interrelationship of the messianic kingdom and God's kingdom, see VanGemeren, Interpreting the Prophetic Word (Grand Rapids, Mich.: Zondervan, 1990), 156-57; his view is that the messiah will establish God's kingdom (p. 156) and the messianic kingdom as continuity of God's kingdom (p. 373). 
Book V) ${ }^{590}$ is the answer. ${ }^{591}$ Therefore, we conclude that a proper understanding of Book IV is essential. The problem before us remains, however, for the apparent ending of the Davidic dynasty (and the revoking/revocation of the Davidic covenant) is the troublesome topic that closes Books I-III. What follows below is a discussion of Book IV in light of the first three books of the Psalter and the apparent failure of the Davidic covenant.

\subsection{A Study of Book IV in View of Books I-III and the Editorial Introduction of Psalms 1-2}

At the outset of our discussion, we should point out that Ps 89:19[18] has already

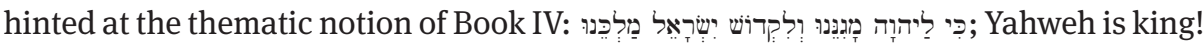
Note that this verse is positioned before a lengthy depiction of the divine oracle of the Davidic dynasty in vv. 20-38[19-37].

Book IV differs considerably from the first three books of the Psalter; Wilson is right when he keenly recognizes how "the untitled psalms predominate" 592 in this collection. The collection should be analyzed in two parts: Psalms 90-100 and 101106. ${ }^{593}$ For Psalms 90-100, Wilson's analysis has rightly concluded with these remarks:

These psalms emphasize a 'pre-monarchic' reliance on YHWH alone that exalts God's wondrous, eternal works in contrast to the weak and transitory nature of humanity. Rather than encouraging confidence in human rulers, these psalms counsel the hearer to find

590 See deClaissé-Walford, Reading from the Beginning, 82; she sees Book IV and V as giving the answer; cf. Harry P. Nasuti, who discusses Wilson's view that Book IV is the answer to the problem (question) posed in Psalm 89. Nasuti, Defining the Sacred Songs: Genre, Tradition and the Post-Critical Interpretation of the Psalms, JSOTSup 218 (Sheffield: Sheffield Academic Press, 1999), 170-71; see Wilson, The Hebrew Psalter, 215; he remarks: "In my opinion, Psalms 90-106 function as the editorial 'center' of the final form of the Hebrew Psalter. As such this grouping stands as the 'answer' to the problem posed in Psalm 89 as to the apparent failure of the Davidic covenant with which Books OneThree are primarily concerned."

591 Some, like Hossfeld and Zenger, Psalmen 51-100, 33, see Psalms 90-92 as an immediate answer to the crisis posed by Psalms 88-89.

592 Wilson further remarks: "Only seven of these 17 psalms have titles at all; and only three of these name an author (Moses in Psalm 90 and David in Psalms 101, 103)." Idem, "Shaping the Psalter," 75. 593 Mitchell, Message of the Psalter, 272. Klaus Koenen, however, proposes to view Psalms 90-106 (in Book IV) with Psalms 107-110 (in Book V) as one compositional block. By stressing contrasting themes including the righteous vs. the evildoers, transitory human beings vs. Yahweh's faithfulness, he sees a double, parallel composition: Psalm 102 corresponds to 90 and 91, 92 to 103, 93 to 104, 95 to 105-107, 96-98 to 108, etc. Finally, he sees 101 as parallel to 110 for both are hymns celebrating royal righteousness and the doom of the enemies and evildoers. Among all these parallels, in our judgment, the subject matter of Psalms 101 and 110 is so incongruent that Koenen is forcing his point there. See Koenen, Jahwe wird kommen, zu herrschen über die Erde, BBB 101 (Weinheim: Beltz Athenäum, 1995). 
refuge in YHWH who alone is eternal and able to save. These themes provide an appropriate introduction to the central YHWH-malak psalms that celebrate the kingship of YHWH. ${ }^{594}$

The notion of Yahweh as king, foreshadowed in Ps 89:19[18], is clearly depicted in Psalms 93, 95-99, where מלך occurs with a clear reference to Yahweh. ${ }^{595}$

Based on our analysis of Psalm 89 and the first section of Book IV (Psalms 90-100), we can conclude two things. First, as depicted in Psalm 89, the Davidic dynasty was deposed; in the history of Israel: the exile. ${ }^{596}$ Second, in contrast to the fate of the Davidic dynasty, the kingship of Yahweh remains strong and calls for celebration (Psalms 93, 96-99). In summary, Yahweh's kingship is still evident in Book IV, at least in the first section of Book IV, despite the historical reality that the Davidic monarchy was sent into exile..$^{597}$

It must be emphasized that the notion of Yahweh's kingship is not the complete thematic picture that comes into focus in Book IV; the מלד-lexeme is wanting in a cluster of six psalms, Psalms 101-106. These six psalms offer hope to the exilic nation ${ }^{598}$ and are significantly tied to the messianic reading as advocated in Psalms 1-2.

Beginning with Psalms 101-103, we discover that Psalms 101 and 103 are the only psalms within Book IV containing a Davidic superscription. Scholars generally regard Psalm 101 as a royal psalm;; ${ }^{59}$ therefore, if David is the speaker, then he is concerned with his (vv. 2, 7), meaning that either he himself or those in his בית have to live a godly life. This is set in stark contrast to the disobedience of the nation taken into exile. Psalm 103, another Davidic psalm ${ }^{600}$ that may suggest that the speaker is a

594 Wilson, "Shaping the Psalter," 76. Note that Wilson's analysis is done for the whole collection. Nonetheless, in our opinion, his result is only true to the first part of Book IV (Psalms 90-100); see our comments later in this chapter for another theme of Book IV.

595 After studying the thematic and linguistic links of Psalms 93-100, Howard concludes that (1) all of these psalms are concerned with Yahweh's kingship and (2) Psalm 96-99 is the heart of this section, bounded by Psalm 95 and 100 as "brackets." Idem, Psalms 93-100, 183. Mitchell, however, calls this psalm-group "the Wilderness of the Nations" (chapter's title) since he is studying this psalm-group in light of Zech 13:7-14:2 (see his Message of the Psalter, chapter 9).

596 Wilson and Tate both view Book IV as containing Exodus (Moses) wandering and exile imagery; see their arguments quoted in Mitchell, Message of the Psalter, 274.

597 Wilson comments: "The central psalms of book four (Psalms 93; 95-99) celebrate the kingship of Yahweh who, unlike human princes, rules forever. In praising the creative power of God, these psalms leave no doubt that the failure of the monarchy in the Exile cannot be attributed to any weakness of God.... The Exile is the result ... of Israel's sin and disobedience." Idem, "The Shape of the Book of Psalms," Int 46 (1992): 140.

598 Wilson views these psalms as "Israel's admission of guilt and repentance before God." Idem, "Book of Psalms," 140.

599 Allen, Psalms 101-150, 3; cf. Kraus, Psalms 60-150, 277.

600 Some scholars view it as "thanksgiving psalm." Allen, Psalms 101-150, 19-20 and Kraus, Psalms 60-150, 290. 
Davidic king, ${ }^{601}$ gives thanks to Yahweh who, based on his character (vv. 8, 13; especially v. 8), forgives sins (v. 3, cf. 9-12). Toward the end of the psalm, two verses contribute significantly to the overall theme of Book IV. First, in view of the failed Davidic covenant, the challenge is sounded (to those who might be in exile) to "keep his covenant (ברית) and to obey his precepts” (v. 18). Second, an allusion to Yahweh's kingship is reiterated in v. 19, ${ }^{602}$ thus ending the psalm with "praises" (vv. 20-22). ${ }^{603}$

Psalm 102, ${ }^{604}$ sandwiched by Psalms 101 and 103, is a song in the midst of lament or complaint, nestled in the theme of exile, or to be more precise, delivered in view of the return from exile set out in 102:13-23[12-22]. Yahweh will rebuild Zion (v. 17[16] $)^{605}$ because of his compassion for her (v. 14[13]). ${ }^{606}$ Hope is offered to an exiled community. Viewed together (101-103), these three psalms resound with the answer to the question posed by Ps 89:50[49]: Yahweh still has love and compassion for the fallen dynasty.

In looking at the next three psalms, 104-106, ${ }^{607}$ we discover that Psalm 104 is a hymn of praise focusing on God's creating and sustaining power, ${ }^{608}$ and since Psalms 105-106 appear to share a similar theme, they should be treated together. ${ }^{609}$ In the midst of the praise in Psalm 104, v. 35a reiterates a theme that links back to Psalms 1-2:

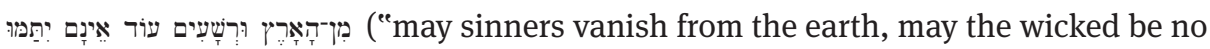
more"). Psalms 105-106 contain a poetic summary of the accounts of the patriarchs; from Abraham to Jacob (105:8-22) to the immigration to Egypt (105:23-25); from Exodus to the desert wanderings $(105: 26-42 ; 106: 7-34)$; and from the conquest of Canaan to the oppression of the times of the judges (105:43-45; 106:35-46). Two verses, one in Psalm 105 and one in 106, tie these two psalms to Psalms 1-2, however. In Ps 105:45, the MT

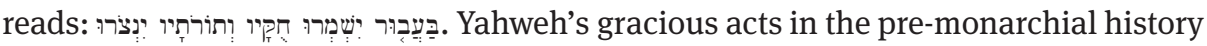
of Israel, ${ }^{610}$ reiterated in both psalms, on the one hand offer hope to a nation in exile.

601 Mitchell, Message of the Psalter, 293.

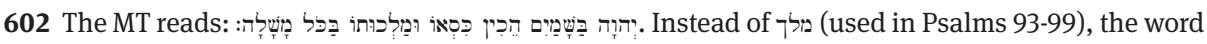
"פַלכוּות "royal dominion" (see HALOT 2: 593) is used.

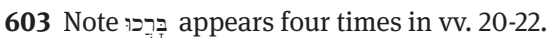

604 Allen recognizes the complexity of Psalm 102 in terms of genre analysis and the multiplicity of interpretations of it. Idem, Psalms 101-150, 11.

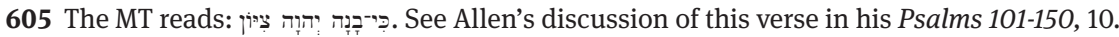

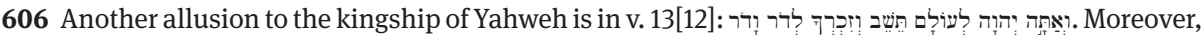
the appeal to Yahweh's compassion ( (anר, v. 14[13]) is a foreshadowing of the same basis on which the forgiveness of sins is granted in Ps 103 (v. 4).

607 G. J. Brooke proposes that these three psalms are chosen to form a conclusion to Book IV. See idem, "Psalms 105 and 106 at Qumran," RevQ 14 (1989-90): 267-92; quoted in Mitchell, Message of the Psalter, 293.

608 Wilson, "Book of Psalms," 141; cf. Sailhamer, Bible Commentary, 339.

609 Cf. Kraus, Psalms 60-150, 308-309.

610 Could this reinforce that Yahweh's kingship is above the human monarchy, as indicated in the first part of Book IV? 
On the other hand, the purpose ${ }^{611}$ of Yahweh's acts is to encourage God's people to go back to the Torah. Furthermore, in Ps 106:6, ${ }^{612}$ the use of רשע reminds the reader of Psalms 1-2; here the poet, or the nation in exile, identifies himself with the forefathers in their disobedience to Yahweh.

We now recap our study of Book IV. The theme of Yahweh's kingship predominates in the first part of Book IV; to answer the question posed in Psalm 89 - despite the fragility of human kingship as illustrated in the fallen Davidic dynasty in exile Yahweh still remains king. The kingship of Yahweh has already been delineated in Psalms 1-2, with special reference to the messianic king. Then, with Yahweh's kingship in the background of the second part of Book IV, key references are presented that bring the reader back to Psalms 1-2; both the vanishing of the wicked and the prominence of the Torah point to a better kingdom, the kingdom of the messianic son. ${ }^{613}$

In conclusion, we have surveyed the tracking of our thematic notion (Torahrevelation-pointing-to-trusting-the messiah) throughout Books I-IV. Specifically, we have looked at psalms $(72,89)$ strategically positioned in Books I-III and also selected a few specific psalms in Book IV. All of these psalms ultimately bring the reader back to Psalms 1-2: the glory or the doom of the Davidic kingdom cannot obstruct, foil, or malign the kingship of Yahweh and his messianic son. In fact, the contrast of these two kingships should ultimately encourage readers to reexamine their faith according to what Psalms 1-2 have already delineated by putting all of their trust in the messianic king of Yahweh. Moreover, in the framework of the Davidic covenant, each of the Books, by the placements of some psalms such as 72 and 89 and verbal contents in psalms such as those found in 102:17[16]), affirms that Yahweh remains faithful to his covenant even though at times the Davidic dynasty appeared to be in shambles.

The work set before us is to continue to track our thematic notion (Torah-pointingto-messiah) in Book V, which is the topic of the next chapter.

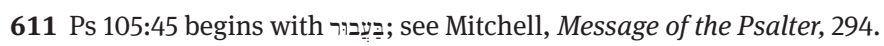

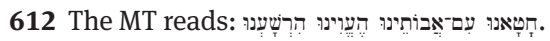

613 See our analysis of the theological interaction of Psalms 1-2 earlier in this chapter. 